\title{
Ecohydrology for compensation of Global Change
}

\author{
Zalewski, M.* \\ International Institute of the Polish Academy of Sciences, \\ European Regional Centre for Ecohydrology under the auspices of UNESCO, \\ Tylna 3 Street, 90-364 Lodz, Poland \\ Department of Applied Ecology University of Lodz, Banacha 12/14 Street, 90-237 Lodz, Poland \\ *e-mail: mzal@biol.uni.lodz.pl \\ Received January 8, 2010 - Accepted June 5, 2010 - Distributed October 31, 2010
}

(With 6 figures)

\begin{abstract}
Water in the XXI century has become the primary factor for sustainable development, eradication of poverty and reversal of ecosystem degradation. Increasing water demand for agriculture and urbanisation, combined with pollution, eutrophication and amplification of the stochastic character of climatic processes, increases water limitations for ecosystems and societies. The transdisciplinary science of Ecohydrology, which has been developed in the framework of the International Hydrological Programme of UNESCO, provides a systemic approach, to regulate hydrology-ecosystemsociety interplay towards: 1) slowing down the transfer of water from the atmosphere to the sea, still considered as a priority to reduce the severity of floods and droughts impact; 2) reducing input and regulating the allocation of excess nutrients and pollutants to aquatic ecosystems, toward reversing ecosystems degradation and improvement of human well being; and 3) harmonisation of ecosystem potential with societal needs within the framework of IWRM.
\end{abstract}

Keywords: ecohydrology, global change, catchment, dual regulation.

\section{Ecohidrologia como compensação às mudanças globais}

\begin{abstract}
Resumo
A Água no século XXI tornou-se o fator primordial para o desenvolvimento sustentável, a erradicação da pobreza e as iniciativas para reverter à degradação dos ecossistemas. O aumento da demanda de águas para a agricultura e urbanização, eutrofização e poluição e a amplificação do caráter estocástico dos processos climáticos aumenta o limite de água disponível para os ecossistemas e as sociedades. A ciência transdisciplinar da Ecohidrologia, que se desenvolve no arcabouço do Programa Hidrológico Internacional da UNESCO, proporciona uma abordagem sistêmica na regulação das interações hidrologia-ecossistema e sociedade. Esta abordagem dá-se através dos seguintes processos e ações: 1) iminuindo a transferência da água da atmosfera para os oceanos, considerando-se esta ação como prioridade para reduzir a severidade das enchentes e secas; 2) Reduzindo a eutrofização e poluição dos sistemas aquáticos continentais revertendo a degradação do ecossistema e melhorando o bem estar humano; e 3) Harmonização do potencial dos ecossistemas com as necessidades da sociedade no arcabouço do programa Gerenciamento Integradas de Recursos Hídricos.
\end{abstract}

Palavras-chave: ecohidrologia, mudanças globais, bacia hidrográfica, regulação dupla.

\section{Introduction}

The dynamics of the water cycle in a river basin depend on climate, geomorphology, plant cover and freshwater ecosystems typology. On the other hand, its modifications and degradation of aquatic habitats depend on the harmonisation of human population density, agriculture, urbanisation, industrial development and hydro-technical infrastructure with the ecosystem potential.

Science of the XXI century has to be not only curiositydriven but, according to the International Council for Science (ICSU), problem-solving and policy oriented. The recent progress in environmental science has been providing evidence that in the Anthropocene Era, the transformation and evolution of humanity from industrial to a postindustrial, sustainable global society, has to be done based on integrative environmental science. If such a paradigm change is not accepted, extinction will become highly probable (Burdyuzha, 2006).

Consequently, reversing the degradation of the biological structure of almost $80 \%$ of Earth, and of fundamental ecological processes such as water and nutrients and water cycles, become the major challenges toward achieving sustainable development in the phase of global climate changes. 
Water management until the end of the $20^{\text {th }}$ century was dominated by a mechanistic approach focused on the elimination of threats such as floods and droughts, and provision of water for societal needs. The biological structure of ecosystems around 1900 was mostly used as an indicator of ecological status (Kolkwitz and Marsson, 1908). Declining water quality on the global scale and increasing progress in the predictive potential of ecology and limnology (e.g. Vollenweider, 1965; Odum, 1969; Margalef, 1983, 1994; Tundisi and Matsumura Tundisi, 2008) provided the background for the development of ecological engineering (Mitsch, 1993; Tundisi and Straskraba, 1999; Mitsch and Jorgensen, 2004), restoration ecology (Aronson and Le Floc'h, 1996; Pedersen et al., 2007) and integrative sustainability science, i.e. Ecohydrology (EH) (Zalewski et al., 1997; Zalewski, 2000, 2008). The basic question from which the formulation of $\mathrm{EH}$ theory initiated is: what is the hierarchy of factors regulating the dynamics of the freshwater community along environmental gradients. According to the Abiotic-Biotic Regulation Concept (ABRC) (Zalewski and Naiman, 1985), the major drivers are hydrology expressed by stream order and temperature as degree days at geographical zones.

The fundamental work of an international team of scientists on defining and testing the primary hypothesis of Ecohydrolgy as a scientific discipline has been developed in the framework of the International Hydrological Programme of UNESCO (IHP Phase V, VI and VII) (Breil et al. 2005; Chicharo et al. 2001; Timchenko, Oksiyuk 2002 Zalewski et al., 1997; Zalewski, 2002; Zalewski and WagnerLotkowska, 2004; Zalewski and Wagner, 2008). Considering progressing degradation of water and ecosystem resources on a global scale, the three major goals of Ecohydrology as a problem-solving science are:

1) slowing down the transfer of water from the atmosphere to the sea, still considered a priority to reduce the severity of the impact of floods and droughts;

2) reducing input and regulating the allocation of excess nutrients and pollutants to aquatic ecosystems, towards reversing ecosystems degradation and improvement of human well-being; and

3) harmonisation of ecosystem potential with societal needs within the framework of IWRM.

The restoration of habitats towards slowing down the transfer of water from the sky to the sea should help to maintain critical habitats by regulation of processes, water, energy and nutrients circulation towards sustainability, which in turn maintains biodiversity. This can not only be done by conservation, but in the face of global climate changes, by hydrological patterns regulation and change of allocation of excess nutrients and pollutants in to no available pool (soil, sediments, wood, biomass/bioenergy, fodder), or at least from more dynamic - opportunistic (e.g. toxic cyanobacteria) to less dynamic pools within organisms (zooplankton, fish, macrophytes) (Zalewski, 2007; Harper et al., 2008). And further, its application can be used to solve societal problems with reference to Integrated Water Resources Management (IWRM).

\section{Ecohydrology - Evolution of a Paradigm}

Ecohydrology is a sub-discipline of hydrology that focusses on ecological processes occurring within the hydrological cycle and strives to utilise such processes for enhancing environmental sustainability.

Ecohydrology based on scientific understanding of the hydrology/biota interplay also provides a systemic framework for how to use ecosystem properties as a new tool for IWRM, complementary to already applied hydrotechnical solutions. The novel element of this approach to restore degradation of aquatic ecosystems is not only protection but regulation towards the enhancement of carrying capacity (water, ecosystem services and biodiversity) of ecosystem resilience and performance from a landscape to a molecular scale. Biocenotic processes are shaped by hydrology and, vice versa, biocenotic structure and interactions shape hydrological processes (Zalewski, 2000, 2006a). In terms of evolution, terrestrial and aquatic organisms have adapted to water quantity and quality dynamics in the catchment. The understanding of evolutionary imprinted organismic adaptation mechanisms and ecologic succession processes have to be used to reverse the degradation of ecosystem biodiversity and to enhance ecosystem services for society. Moreover, ecosystem properties have to be considered as a new management tool toward reversing degradation and as water dynamic on the catchment scale (e.g., Zalewski, 2000; Zalewski et al., 2008). The evolving paradigm has been the change from interdisciplinarity to transdisciplinarity by harmonising societal goals with ecosystem potential. Due to the complexity of applied knowledge, the development of mathematical models for decision support systems should be an important tool to test alternative scenarios and implement $\mathrm{EH}$ methodology for sustainable water use, ecosystems and societies.

Such a transdisciplinary approach, which integrates different disciplines of environmental sciences toward societal goals and aspirations taking into account cultural heritage (Berton and Bacchi, 1997), creates a new opportunity to achieve sustainable development. The future of the biogeosphere and anthroposphere and its peaceful coevolution will be dependent not only on the development of technologies but to a greater extent, on the harmonisation of technologies with the potential of the environment, based on the cultural heritage of societies.

\section{Ecohydrology - the Terrestrial and Aquatic Dimension}

The scientific catchment approach and its implementation for IWRM encompass an atmospheric/terrestrial and an aquatic phase of the hydrological cycle. In both, diverse biota appear as moderators of water dynamics. In the terrestrial phase (EHT), vegetation moderates water quantity and quality, and the major question is how land-cover 
changes influence the hydrological cycle in the sense of water balance and nutrients/pollutants transfer across the landscape in to freshwaters. In the aquatic phase (EHA), complicated biotic interactions determine water quality, related symptoms of eutrophication (e.g., toxic algal blooms) and biomagnification in food chains of heavy metals, and permanent organic pollutants (POP) such as dioxins, PCB and pesticides.

The reduction of point source pollution is dependent on technology, monitoring and law enforcement. However, the impact reduction of diffuse pollution without lowering food production is dependent, first of all, on understanding the hierarchical complexity of ecological processes in the river basin. Of utmost importance is the interplay between water and biocenosis - both in the terrestrial and aquatic phases of the hydrological meso-cycle.

Both EHT and EHA require multidisciplinary and interdisciplinary cooperation of basic scientific disciplines (e.g. Tilman, 1996; Baird and Wilby, 1999; Rodrigues-Iturbe, 2000; Zalewski, 2000). A key component of this paradigm is the aspect of "problem solving". Hence, ecosystem properties have become management tools to achieve sustainable development by respecting the quantitative side of the hydrological cycle where supporting tools are remote sensing, GIS techniques and mathematical modelling (Jorgensen, 2002). They are crucial to formulate bold hypotheses which consider multiple trajectories of precisely quantified processes with rigid explicit criteria of Popperian falsification. All of these hypotheses lead to efficient implementation of catchment scale systemic solutions and help to avoid a "trial and error" approach.

\section{Water and Temperature - Major Drivers of Distribution the Global Biodiversity}

As far as a fundamental cumulative indicator of human well-being and the prospects for sustainable future biodiversity are concerned, we have to define what the major drivers determining global biodiversity are. It is well known that water availability determines plant yield (Visser, 1971) and that the increase of biomass is highly correlated with solar radiation (Kowalik and Eckersten, 1984; Kedziora, 1996). Following these dependencies, the hypothesis introduced by Zalewski (2002b) suggests that in the given geomorphological conditions, water and temperature are the major determinants of biodiversity (Figure 1). It is because the amount of water determines the amount of carbon accumulated in the ecosystem while temperature determines the carbon allocation between biomass and soil organic matter. With increasing temperature from boreal to tropical zones, there is a significant shift toward increased carbon accumulation in biomass. This is the result of the Van Hoff law that relates the acceleration of organic matter decomposition processes with temperature increase. As far as decomposition of organic matter in the soil is concerned, it can be even 40 times faster in the tropics than in boreal zones. Thus the conditions for diversification of microbial, plant and animal communities, persistence of favourable

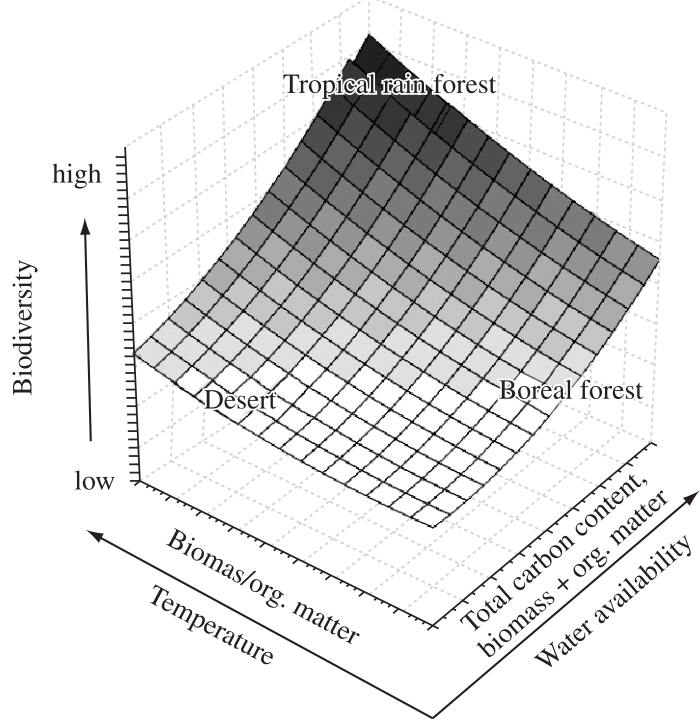

Figure 1. The general distribution of global biodiversity as an effect of sun energy access and water availability. Total carbon content increases with water availability. The water and temperature determine primary productivity and the rate of energy flow through the ecosystem; the temperature determines the ratio of decomposition, thus nutrient cycle dynamics; and the ratio of carbon allocation between biomass and organic matter which indicates the dynamics of energy flow through the ecosystem (Zalewski, 2002b).

mutation and, consequently, the natural selection and adaptation processes become more favourable orders of magnitude. Additionally, in boreal zones, the short growing period for plants provides a very limited flow of energy and nutrients, and in consequence, catastrophic events may randomly eliminate emerging new genomes.

\section{Principles of Ecohydrology as a Framework for Scientific Investigation and Problem-solving Implementation}

The hydrological principle - The quantification and integration of hydrological and biological processes at the basin scale is based on the assumption that abiotic factors are of primary importance and become stable and predictable when biotic interactions start to manifest themselves (Zalewski and Naiman, 1985) (Figure 2). The quantification covers the patterns of hydrological pulses along the river continuum and monitoring of point and non-point source pollution to regulate processes toward sustainable water use and ecosystem protection.

The ecological principle - The ecological principle is based on the assumption that under intensive global changes, it is not enough to protect ecosystems against increasing human population, energy consumption and aspirations (Figure 3). It is necessary to regulate ecosystem structure and processes toward increasing the "carrying capacity" (water quality, restoration of biodiversity, ecosystem services for 


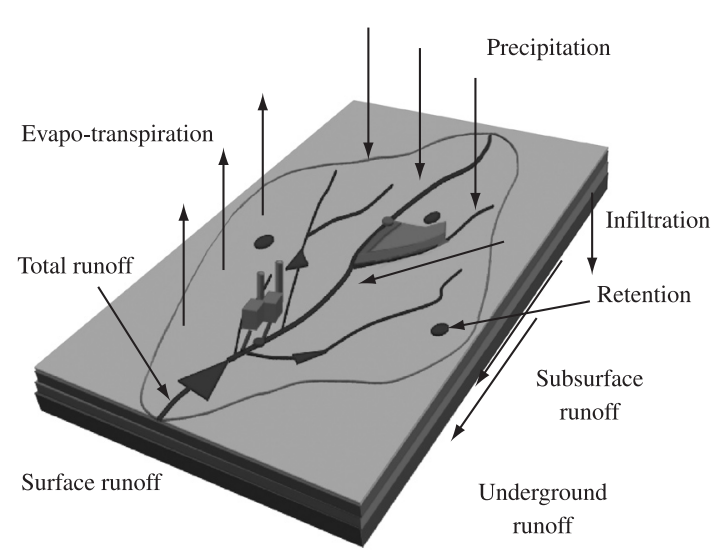

Figure 2. First Principle - Hydrological - quantification of hydrological cycle analysis from the point of view of socioeconomy and spatial-temporal dynamic vs. various forms of human impact.

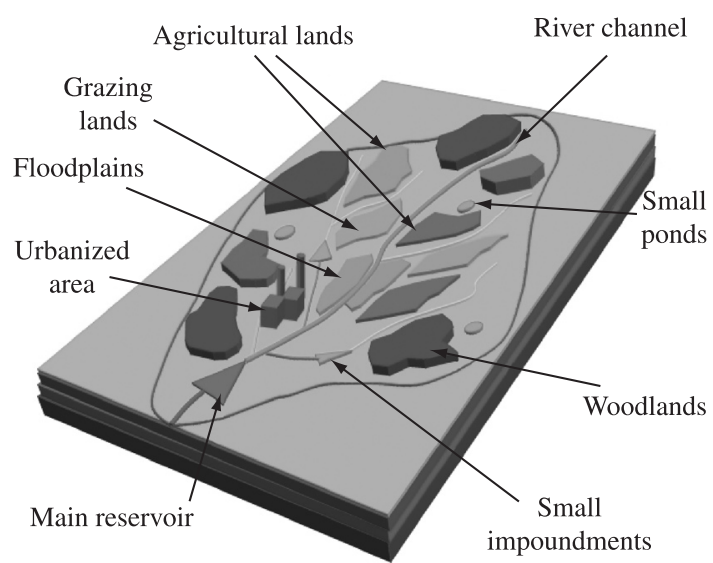

Figure 3. Second Principle - Ecological - the analysis of distribution of various types of biocenosis and its potential to enhance resilience and absorbing capacity for human impact (GIS).

society, resilience of river ecosystem). Understanding the role of vegetation in water cycling processes is of crucial importance (Vorosmarty and Sahagian, 2000; Kedziora and Ryszkowski, 1999).

The ecotechnological principle - The use of ecosystem properties as a management tool is based on the first and second principles of $\mathrm{EH}$ and related to ecological engineering (Figure 4). This principle features three steps of implementation:

1) "Dual regulation" - biota by hydrology and, vice versa, hydrology by shaping biota or controlling interactions;

2) Integration at the basin scale of various types of biological and hydrological regulations toward achieving synergy to improve water quality, biodiversity and freshwater resources; and

3) Harmonization of ecohydrological measures with necessary hydrotechnical solutions (dams, irrigation systems, sewage treatment plants, etc).
The integration for synergy at the basin scale mentioned, and many other regulatory measures (Zalewski, 2000), have been reducing the negative effect of the excessive nutrients pollutants load into aquatic system significantly.

Finally, the harmonisation of such solutions with societal needs has been introduced in Figure 5, where a low efficiency sewage plant was enhanced by constructed wetland based on the local species of willows, which were distributed according to their tolerance to flooding to increase efficiency of the absorption of nutrients. The conversion of Phosphorus, which instead of enriching the reservoir, stimulates bioenergy production, reduces $\mathrm{CO}_{2}$ emission and creates employment opportunities, is an example of an ecohydrological systemic solution (EHSS). The broad range of cases, such as EHSS, has been under implementation in the different continents in the framework of the International Hydrological Programme of UNESCO IHP VII Phase (Harper, Zalewski and Wagner, 2009).

\section{The Role of Reservoirs for Compensating Global Change}

In the face of global change considered as climate stochastic increase and population quality of life improvement, the role of reservoirs in ecological flow regulation has to be reconsidered (e.g. Ward and Stanford, 1979; Lillehammer and Saltveit, 1984; Petts, 1984; Power et al., 1996).

A good example is provided by the climatic scenarios of the HELCOM in the South Baltic Sea catchment where annual precipitation is $600 \mathrm{~mm}$ and $60 \%$ of the area is agricultural land, summer river flow may decrease even to $50 \%$, whereas in winter, it may increase up to $70 \%$ (HELCOM, 2007). If such drastic changes appear, extreme floods and droughts, especially in agriculture and urbanised catchments, will be severe threats for sustainable development. As a consequence, in catchments where land cover has been modified by humans, new dams constructed with enhanced resilience to eutrophication (e.g. pre-reservoirs such as the one constructed on the river Zala, which reversed eutrophication of the Balaton Lake) (Tátrai et al., 2000), and with bypass systems for maintaining the migration and restoration of reophilic fish (Zalewski and Welcomme, 2001; Zalewski, 2006b) should minimise the negative effects of impoundments on ecological processes and biodiversity, and increase river basin resilience (Figure 6).

\section{Discussion}

From the methodology of the scientific perspective, the fundamental aspects of environmental sciences are based on empirical analysis of the structure and functional relationships between the various abiotic and biotic components of the environment. On the other hand, the key to advance science is the distillation of the general patterns from surrounding commonalities. Ecohydrology, considering the freshwater ecosystem from the catchment perspective, contains both elements. Moreover, it defines a new target 


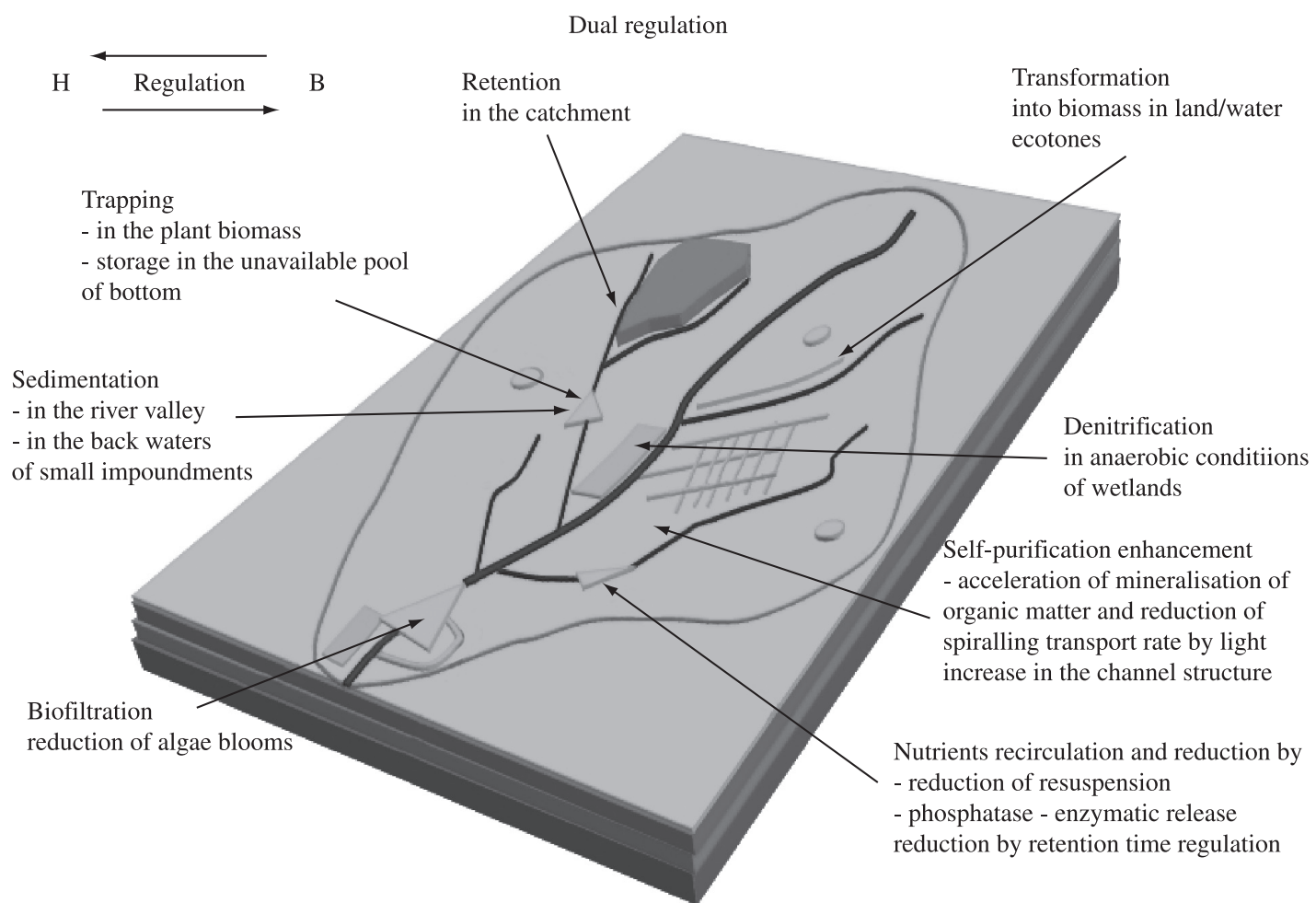

Figure 4. Third Ecohydrological Principle - use of biota to control hydrological processes and vice versa, using hydrology to regulate biota.

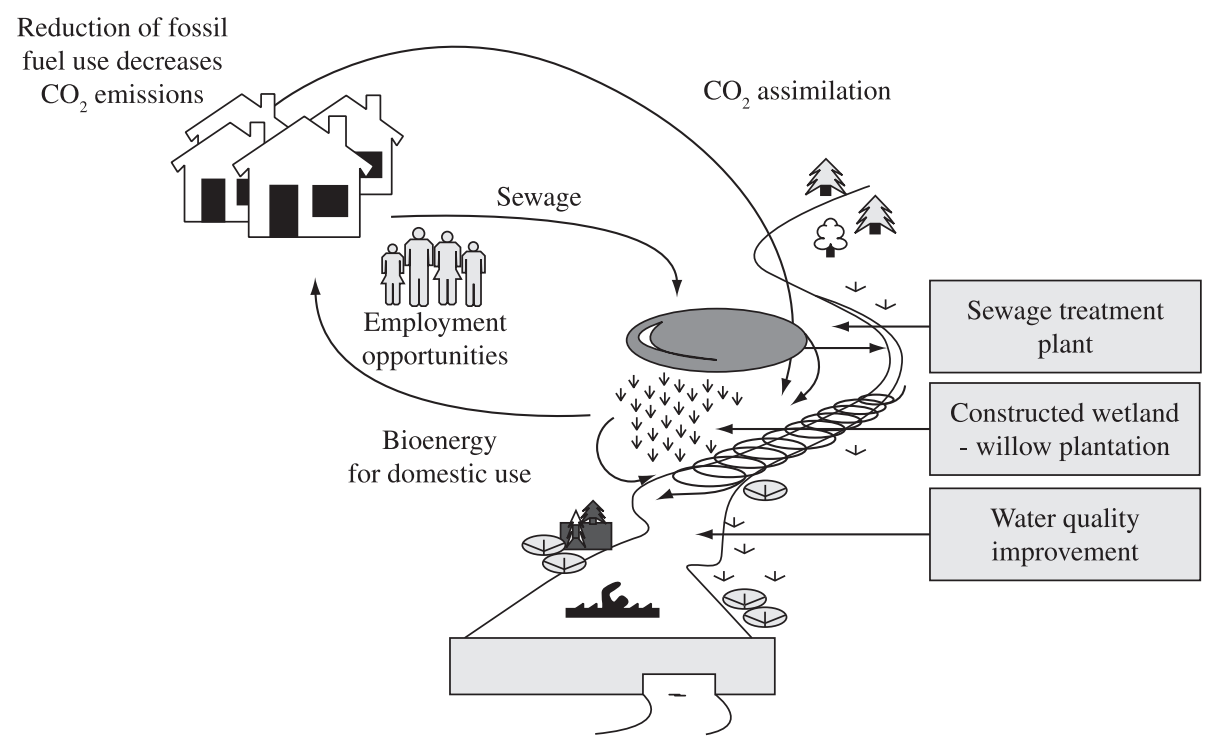

Figure 5. System solutions based on three principles - improvement of ecological flow, water quality, human health and quality of life (modified from Zalewski and Robarts, 2003).

- in the face of broadly understanding global changes (climate, land cover, ecological processes, demography), it articulates the need for regulation of processes on the scale of the hydrological mesocycle-basin. In parallel, it provides new "know how" to regulate processes from the molecular to landscape level highlighting how to use, imprinted by evolution, the ability to adapt terrestrial and aquatic organisms to water dynamics in the landscape, and how to use the understanding of such feedbacks for the reduction of hydrological extremes (floods, droughts) and water quality improvement e.g. Zalewski et al., 1990. Also, vice versa, how by shaping biotic communities one 


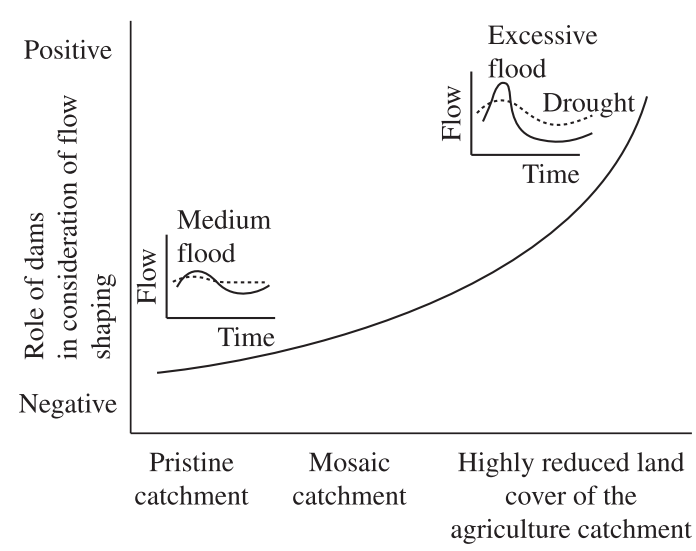

Figure 6. Positive role of dams in consideration of ecological flow shaping in highly modified landscapes, in the face of global climate changes.

may regulate dynamics and especially the water quality in the terrestrial and aquatic systems incorporated in basin critical "red spots" in constructed wetlands (e.g. Mitsch and Jorgensen, 2004; Tundisi and Matsumura Tundisi, 2008). The integration for synergy of those two aspects: river basin processes regulation ( $\mathrm{H}-\mathrm{B}$ and $\mathrm{B}-\mathrm{H})$ has been termed "dual regulation" (Zalewski, 2006a). However, EH methods can be less efficient and have a lower potential when extreme degradation of the ecosystem appears, e.g., in the case of hypertrophy (Zalewski, 2000), because the abiotic environment is so drastically changed that the biotic structure is highly degraded, thus losing its potential to regulate hydrological processes e.g. water quality. Ecological biotechnologies used in the framework of EH become the fundamental tool for successful implementation of Integrated Water Resources Management.

At the beginning of their scientific career, environmental science specialists prefer to deal with the effect of a single factor on single species. However, aquatic ecosystems in particular, are complex entities, whose structure and dynamics are dependent on atmosphere, catchment geomorphology/ land cover and human impact. This, in turn, means that if the homeostasis of such a system is disturbed, simple sectorial solutions are usually insufficient. Thus the key to regulate such complex system performance has to be an integrative transdiscyplinary science.

Following Nelson Mandela's affirmation that "Action without vision is wasting time and resources", there is a need to formulate vision on the basis of foresight methodology

This should consider the recent dynamic development of integrative, transdisciplinary science and the need for change in society's attitude through participatory education, e.g. learning alliances methodology (Moriarty et al., 2007) and the active participation of society in a process of adaptive management (Olsson et al., 2006) toward reversing degradation and achieving harmony between the water environment and society.

\section{References}

ARONSON, J. and LE FLOC'H, E., 1996. Vital landscape attributes: Missing tools for restoration ecology. Restoration Ecology, vol. 4, p. 377-387.

BAIRD, AJ. and WILBY, RL. (Eds), 1999. Eco-hydrology. Plants and water in terrestrial and aquatic environments. London: Routledge.

BERTON, J-P. and BACCHI, M., 1997. Données générales sur le patrimoine écologique ligérien. Actes du Colloque "La gestion patrimoniale de l'Hydrosystème ligérien", p. 3-8.

BREIL, P., MAKSIMOVIC, C. and ZALEWSKI, M., editors, 2005. Proceedings of the International UNESCO Workshop: Aquatic Habitats in Integrated Urban Water Management. within the framework of the International Hydrological Programme (IHP) and the Man and the Biosphere (MAB) Programme 18-20 September 2005, Łódź, Poland. Ecohydrology and Hydrobiology, vol. 5 , no. 4 .

BURDYUZHA, V., 2006. The Future of Life and the Future of our Civilization. Dordrecht, The Nederlands: Springer, 495 p.

CHICHARO, L., CHICHARO, MA., ESTEVES, E., ANDRADE, P. and MORAIS, P., 2001. Effects of alterations in fresh water supply on the abundance and distribution of Engraulis encrasicolus in the Guadiana estuary and adjacent coastal areas of south Portugal. Ecohydrology \& Hydrobiology, vol. 1, no. 3, p. 341-347.

HARPER, D., ZALEWSKI, M., PACINI, N., 2008. Ecohydrology: Sustainable Management of Water Resources. London: CAB International. $391 \mathrm{p}$

HARPER, D., ZALEWSKI, M. and WAGNER, I., editors, 2009. Special issue on Ecohydrology - needs and opportunities throughout the world: the UNESCO-IHP Demonstration Projects in Ecohydrology. Ecohydrology and Hydrobiology, vol. 9, no. 1, $134 \mathrm{p}$.

Helcom. Climate Change in the Baltic Sea Area. Helcom Thematic Assessment in 2007. Baltic Sea Environment Proceedings, no. $111.49 \mathrm{p}$.

JORGENSEN, SE., 2002, Explanation of ecological rules and observation by application of ecosystem theory and ecological models. Ecological Modelling, vol. 158, p. 241-248.

KEDZIORA, A. and RYSZKOWSKI, L., 1999. Does plant cover structure in rural areas modify climate change effects? Geographia Polonica, vol. 72, no. 2, p. 65-88.

KEDZIORA, A., 1996. Hydrological cycle in agricultural landscales. In RYSZKOWSKI, L., FRENCH, N. and KEDZIORA, A. Dynamics of an agricultural landscape. Poznan: PWRiL. p. 65-78.

KOLKWITZ, R. and MARSSON, M., 1908. Oekologie der pflanzlichen Saprobien. Berichte der deutschen Botanischen Gesellschaft, vol. 26, p. 505-519.

KOWALIK, P. and ECKERSTEN, H., 1984. Water transfer from soil through plants in the atmosphere in willow energy forest. Ecological Modeling, vol. 26, p. 251-284.

LILLEHAMMER, A. and SALTVEIT, SJ., 1984. Regulated rivers. Olso: Unversiteitsforlaget.

MARGALEF, R., 1983. Limnologia. Barcelona: Ediciones Omega. $1010 \mathrm{p}$.

MARGALEF, R., 1994. Limnology Now: a paradigm of planetary problems. Amsterdam: Elsevier Science. 
MITSCH, WJ. and JORGENSEN, SE., 2004. Ecological Engineering and Ecosystem Restoration. New York: John Wiley \& Sons. $411 \mathrm{p}$.

MITSCH, WJ., 1993. Ecological Engineering - a co-operative role with planetary life support system. Environmental Science Technology, vol. 27, p. 438-445.

MORIARTY, P., BATCHELOR, C., ABD-ALHADI, FT., LABAN, P. and FAHMY, H., 2007. The EMPOWERS approach to water governance: guidelines, methods and tools. Amman, Jordan: INWRDAM. 153 p.

ODUM, EP., 1969. The strategy of ecosystem development. Science, vol. 164, p. 262-270.

OLSSON, P., GUNDERSON, LH., CARPENTER, SR., RYAN, P., LEBEL, L., FOLKE, C., HOLLING, CS., 2006. Shooting the rapids: navigating transitions to adaptative governance of socialecological systems. Ecology and Society, vol. 11, no. 1, p. 18.

PEDERSEN, ML., ANDERSEN, JM., NIELSEN, K., LINNEMANN, M., 2007. Restoration of Skjern River and its valley. General ecological changes in the project area. Ecological Engineering, vol. 30, p. 131-144.

PETTS, GE., 1984, Impounded rivers. Perspectives for ecological management. Chichester, UK: Wiley \& Sons.

POWER, ME., DIETRICH, WE. and FINLAY, JC., 1996. Dams and Downstream Aquatic Biodiversity: Potential Food Web Consequences of Hydrologic and Geomorphic Change. Environmental Management, vol. 20, no. 6, p. 887-895.

RODRIGUES-ITURBE, I., 2000. Ecohydrology: A hydrological perspective of climate-soil-vegetation dynamic. Water Resource Research, vol. 36, p. 3-9.

TÁTRAI, K., KORPONAI, MJ., PAULOVITS, G. and POMOGYI, P., 2000. The role of the Kis-Balaton water protection system in the control of water quality of Lake Balaton, Ecological Engineering, vol. 16 , p. $73-78$.

TILMAN, D., 1996. Biodiversity: Population Versus Ecosystem Stability. Ecology, vol. 77, no. 2, p. 350-363.

TIMCHENKO, V. and OKSIYUK, O., 2002. Ecosystem condition and water quality control at impounded sections of fivers by the regulated hydrological regime. Ecohydrology and Hydrobiology, vol. 2, no. 1-4, p. 259-264.

TUNDISI, JG. and MATSUMURA TUNDISI, T., 2008. Limnologia. São Paulo: Oficina de Textos. 632 p.

TUNDISI, JG. and STRASKRABA, M. (Eds), 1999. Theoretical Reservoir Ecology and its Applications. Leiden: International Institute of Ecology. Brazilian Academy of Sciences and Backhuys Publishers. p. 53-173.

VISSER, WC., 1971, Mathematical models in soil productivity studies, exemplified by the response to nitrogen. Plant Soil, vol. 30 , no. 2, p. 161-182.

VOLLENWEIDER, RA., 1965. Scientific Fundamentals of the Eutrophication of Lakes and Flowing Waters, with Particular Reference to Nitrogen and Phosphorus as Factor in Eutrophication. Paris, France. OECD Tech. Rep. DAS CSI 68. 27.

VOROSMARTY CJ. and SAHAGIAN D., 2000. Antropogenic disturbance of the terrestrial water cycle. Bioscience, vol. 50, p. 753-765.

WARD, JV. and STANFORD, JA. (Eds.), 1979. The ecology of regulated steams. New York: Plenum.
ZALEWSKI, M, 2007. Ecohydrology as a Concept and Management Tool. In KING, C., RAMKINSSOON, J., CLÜSENER-GODT, M. and ADEEL, Z. (Eds.). Ecohydrology as a concept and management tool. Canada: UNU-INWEH UNESCO MAB. p. 39-53.

-, 2000. Ecohydrology - The scientific background to use ecosystem properties as management tools toward sustainability of water resources. Guest Editorial Ecological Engineering, vol. 16, p. 1-8.

-, 2002a. Guidelines for the Integrated Management of the Watershed - Phytotechnology and Ecohydrology. United Nations Environment Programme, Division of Technology, Industry and Economics. International Environmental Technology Centre. 188 p. Freshwater Management Series, 5.

-, 2002b. Ecohydrology — the use of ecological and hydrological processes for sustainable management of water resources. Hydrological Sciences-Journal-des Sciences Hydrologiques, vol. 47 , no. 5 , p. 825-834.

-, 2006a. Flood pulses and river ecosystem robustness. Frontiers in Flood Research. In TCHIGUIRINSKAIA, I., NI NI THEIN K. and HUBERT P. (Eds). Kovacs Colloquium. Paris: UNESCO. 212 p. IAHS Publication 305.

-, 2006b,. Mozliwosci wykorzystania ekohydrologii do osiagania dobrego stanu ekologicznego rzek na przykladzie planowanego zbiornika Nieszawa. Gospodarka Wodna, vol. 10, p. 379-381.

-, 2008. Ecohydrology - framework for implementation of ecological biotechnologies in Integrated Water Resources Management (IWRM). Folia Geographica, vol. 39, p. 55-62.

ZALEWSKI, M. and NAIMAN, RJ., 1985, The regulation of riverine fish communities by a continuum of abiotic-biotic factors. In ALABASTER, JS. (Ed.). Habitat Modifications and Freshwater Fisheries. Butterworths, London: FAO UN, p. 3-9.

ZALEWSKI, M. and ROBARTS, R., 2003. Ecohydrology - a new Paradigm for Integrated Water Resources Management. SIL News, vol. 40, p. 1-5.

ZALEWSKI, M. and WAGNER-LOTKOWSKA, I., 2004. Integrated Watershed Management - Ecohydrology and PhytotechnologyManual. UNESCO IHP, UNEP IETC. 246 p.

ZALEWSKI, M. and WELCOMME, R., 2001. Restoration of sustainability of physically degradeted fish habitats - The Model of Intermediate Restoration. Ecohydrology \& Hydrobiology, vol. 1, no. 3, p. 279-282.

ZALEWSKI, M., BREWIŃSKA-ZARAŚ, B., FRANKIEWICZ, P. and KALINOWSKI, S., 1990. The potential for biomanipulation using fry communities in a lowland reservoir: cocordance between water quality and optimal recruitment. Hydrobiologia, vol. 200/201, p. 549-556.

ZALEWSKI, M., HARPER, D., DEMARS, B., JOLANKAI, G., CROSA, G., JANAUER, G. and PACINI, N., 2008. Linking Biological and Physical Processes at the River Basin Scale: the origins, scientific background and scope of Ecohydrology. In HARPER, D., ZALEWSKI, M. and PACINI, N. Ecohydrology: Sustainable Management of Water Resources. London: CAB International. $391 \mathrm{p}$.

ZALEWSKI, M., JANAUER, GA. and JOLANKAI, G., 1997. Ecohydrology. A new paradigm for the sustainable use of aquatic resources. Paris: UNESCO. 60 p. UNESCO IHP Technical Document in Hydrology, 7. IHP - V Projects 2.3/2.4. 